How to Cite

Andriyono, S. (2018). Overview of Indonesia fisheries sector: Java and Bali island. International Journal of Life Sciences \&

Earth Sciences, 1(1), 39-48. https://doi.org/10.31295/ijle.v1n1.12

\title{
Overview of Indonesia fisheries sector: Java and Bali Island
}

\author{
Sapto Andriyono \\ Universitas Airlangga, Surabaya, Indonesia \\ Email: sapto.andriyono@fpk.unair.ac.id
}

\begin{abstract}
As the hot spot of marine biodiversity, Indonesia becomes the world's spotlight in the management of natural resources, especially fish resources. Management of fishery resources in Java and Bali is very important because development in Indonesia is still centered on the island of Java. Capture fisheries in Java Island and some parts of Western Indonesia have been overfishing and need to get serious attention, while in Central and Eastern Indonesia that still has abundant fishery resources it is necessary to manage so as not to experience similar things such as illegal, unreported and unregulated fishing activities. One of the efforts of marine resource management has been done is through the conservation area approach that is now beginning to feel the benefits. Nevertheless, the documentation of Indonesia's marine fishery resources is still very limited, especially at the level of molecular information. Therefore, there is a need for simultaneous research and study supported by all aspects.
\end{abstract}

Keywords---biodiversity, fisheries, Indonesia, marine resources.

\section{Introduction}

As the maritime country, Indonesia has the largest sea area and approximately seventeen-thousands of islands scattered in the archipelago region, has the economic potential of both biological and non-biological in the maritime sector (Nuryadin et al., 2016). In a biological aspect, Indonesia include of The Indo-Malay-Philippines Archipelago (IMPA) (Carpenter \& Springer, 2005; Roberts et al., 2002), has long been considered the area of highest marine biodiversity, supporting mega-biodiversity. In another reference, Indonesia includes the Indo-Australia Archipelago (IAA) or Kepulauan Melayu (Hutama et al., 2017).

In this overview, the study areas are Java and Bali due to of the similarity of biogeography between Java Island and Bali Island that include in one region of biogeography grouping. Biogeography is a study in biological science that emphasizes evolutionary biology which aims to know the origin of the distribution of living things on earth. In relation to Indonesian biogeography, the grouping is distributed in tropical regions which have geographic complexity in nearly 2,000 islands. In this region, the distribution of biogeography is divided into 3 parts: Sundaland in the West, Wallacea in the middle and Sahul in the East (Hutama et al., 2017).

Nearly sixty-five percent of the Indonesia populations live in coastal and marine areas (Wiryawan et al., 1999) and almost all major cities in Java Island and Bali Island are located in coastal areas such as Jakarta, Serang, Semarang, Surabaya, and Denpasar. Java Island which is the most populous island in Indonesia, with its various pressures, still save considerable fishery resources. Several major landing sites are located in Java Island and accompanied by a promising market potential as major cities in Java Island also serve as a marketing place as well as a growing fish processing industry c. There are only 2 major ports in Java which are lending sites for large fishing vessels, namely in Jakarta and Cilacap (FAO, 2016).

\section{Research Method}

Based on the port level category, the Government of Indonesia (Ministry of Marine and Fisheries) divides into four groups namely Fishery Ocean port, Fishery archipelago port, Fishery coastal port, and Fish landing base fishery landing quay. In Java Island, fishery ocean port category is located in Jakarta and Central Java, while fishery 
archipelago port category is six places spread in West Java (two ports) Central Java one port), East Java (two ports) and Banten (one port). In the third category of fishery archipelago port, the number increase with a total in Java Island amounted to 25 places. In the 4th category of fishery landing quay, on the island of Java, there are 243 places. While on the island of Bali, the number of fishing ports is not as much as in Java. In this island, only one fishery archipelago port and seven fishery landing quay (BPS, 2017).

With the support of the capture fisheries facilities, Indonesia's catch fishery sector is the second largest catch fishery after China with the total catch in 2014 of 6,016,525 tones or an increase of 7\% from the previous year (FAO, 2016). However, fishing arrangements need to be addressed. The Indonesian fisheries policy is based on an agreed MSY that is $80 \%$ of the MSY value. The value of MSY is expected to be higher than the total yield of maximum economic return (Gulland, 1983). Based on statistical data from Indonesian marine and fishery ministries, Indonesia's sustainable fishery potential of 7.3 million tons per year ( $80 \%$ of MSY) and 5.8 million tons is total allowance catch (TAC). In 2002, the results of this MSY dating study indicate that actual catches in 2002 only amounted to 4.4 million tons (Widodo, 2003). Nevertheless, of its potential, about $90 \%$ has been utilized from TAC (BPS, 2017).

\section{Results and Analysis}

\section{Biodiversity Marine Fish and Taxonomic Challenges}

The increasing population in Java Island causes changes and land conversions that impact on changes in natural biodiversity structures in both land, estuary and marine ecosystems. The marine ecosystem in Java Island is influenced by two marine ecosystems, Java sea in the north and the Indian Ocean in the south (Sharp, 1996). The uniqueness of the two ecosystems makes Java Island has very interesting characteristics. Compare to the other nation in the Indian Ocean, Indonesia has 3,215 fish species and the highest (Wafar et al., 2011).

The length of Java coastline and Bali Island are respectively $4.135 .51 \mathrm{~km}$ and $633.35 \mathrm{~km}$ which is almost 6.5 times longer (BPS, 2017). With the potential of this coastal fishery, it is possible to provide fishery resources for the community as a source of food and become a livelihood. With regard to information on Biodiversity of fish, information on freshwater fish diversity is more complete when compared to biodiversity marine fish species information. Research on freshwater fish found 1,172 native species that are highly valuable Ichthyofauna Indonesia in world fisheries (Hubert et al., 2015). The diversity of habitats in Indonesia leads to the high potential of the resulting diversity. Two possible habitats for the new marine taxa are the coral reefs and deep troughs that are currently very low in sampling and study in this region (Eschmeyer et al., 2010). It is estimated that marine fish species that still have to be studied are about 5,000, or twice the amount described in the last 19 years, for an estimated number of about 21,800 species of valid marine fish. While the data of marine fish biodiversity in Indonesia is never explained in detail, and even marine biodiversity research is still concentrated on the study of a number of important fish species such as Grouper, shark (Prehadi et al., 2014), short body mackerel (Indaryanto et al., 2015) and tuna (Crandall \& Riginos, 2014). Identification of marine fish, often difficult due to geographical and very difficult sampling location. The condition of Indonesia with the thousands of islands led to the collection of information on marine fish biodiversity is very limited.

Fish identification is traditionally done based on external morphological information, which includes body shape, color pattern, scale size and amount, number of fin positions and type of fin radius, and various relative sizes of body parts (Strauss \& Bond, 1990). With some limitations in the morphological identification, identification without relying on morphological features becomes a necessity. This can be done by characterizing specific proteins by electrophoretic techniques such as isoelectric focusing IEF (Rehbein et al., 1999), capillary electrophoresis (Kvasnička, 2005), high-performance liquid chromatography of HPLC or immunoassay systems such as ELISA (Hubalkova et al., 2007). With the development of technology, the identification switches to DNA as a source of information. As an alternative to protein analysis, DNA identification methods have been developed recently (Teletchea et al., 2005). DNA-based identification is certainly a powerful alternative method (Teletchea, 2009).

\section{Commercial Marine Fish Species of Java and Bali}

Global capture fisheries production in 2014 is 93.4 million tons, comprising 81.5 million tons of capture fisheries production in marine waters and the remaining 11.9 million tons from freshwaters. Capture fisheries production in marine waters, China is ranked top, and Indonesia is in the next position (BPS, 2017). As for the production of capture fisheries in China's freshwaters is still a superior while Indonesia is ranked $7^{\text {th }}$ (FAO, 2016). This statistical 
data shows that the potential of Indonesia's marine waters contributes greatly to the income and fulfillment of food sources for Indonesia.

Indonesia's marine fisheries resources that have been explored are reported in the statistics of Marine and Fisheries annually. The data includes species of demersal fish, small pelagic, large tuna (Figure 1). While the other 2 groups of fish are groups of shrimp and mollusks (squid) (BPS, 2017).

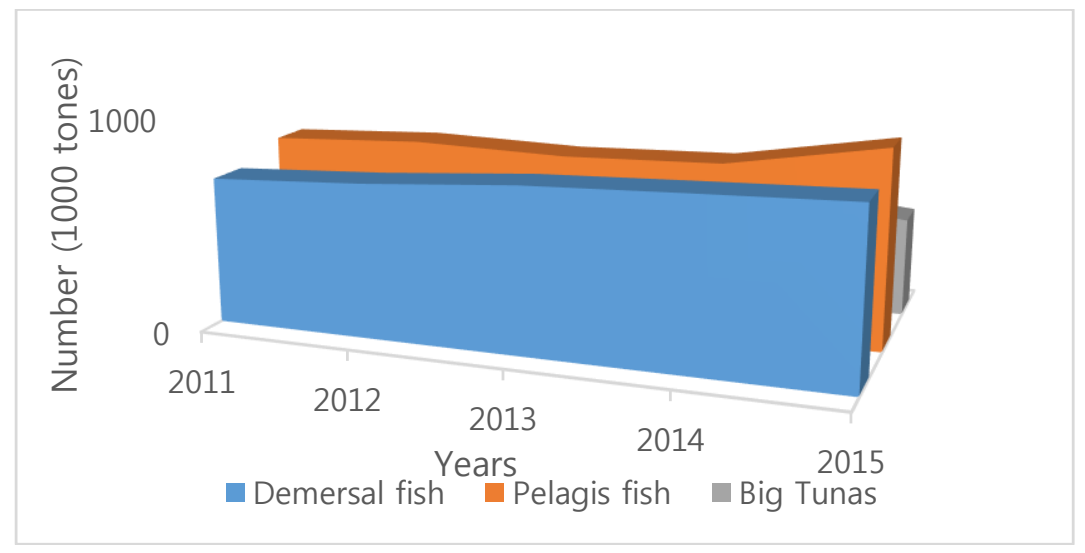

Figure 1. Number of Demersal Fish, Small Pelagic Fish and Big Tunas which is exploited in Java and Bali area

Groups of demersal fish are Four finger Threadfin, Giant Catfish, Hairtails, Treadtins Breams, Sulfur Goalfish, Big Eyes, Greater Lizardfish, Wolf Herrings, Crackers Drums, Res Snappers, Grouper, Jack Travelers, and Flatfishes (McManus, 1989). This group of demersal fish is generally carried out by traditional fishermen (or called coastal fisheries) with a fishing on shallow water.

Small pelagic fish groups include Indian mackerel, Short-bodies mackerels, flying fishes, Scads, and Bali Sardinella (Patterson, 1992). Fishermen who do small pelagic fish groups make arrests in the exclusive economic zone that sail about 1-2 weeks, depending on the capabilities and capacities of the ship used. While in the large tuna groups include skipjack tuna, Albacore, marlin, Indo Pacific Sailfish, and Common dolphin fish. In the tuna fishing group, the fishing boats used have applied more sophisticated technology with better fishing gear than before. Sailing vessels that have entered the general public demand adequate security facilities and good crew skills. Generally, tuna ships are owned by companies that have cooperated with fish processing industry so that when landing, processing companies have been directly picked up the catch and ready in the process according to the type of product produced.

In detail, the exploitation of fish groups is divided into 3 regions, namely the north of Java, southern Java and Bali (Figure 2). The MMF statistics show that capture fisheries in the northern part of Java are more productive with average annual production value of 141.47 tones (demersal fish), 168.9283 tones Small pelagic) and 44.78 tones (big tuna) or 3-4 times larger than region South Java and 1-4 times larger than Bali (BPS, 2017).

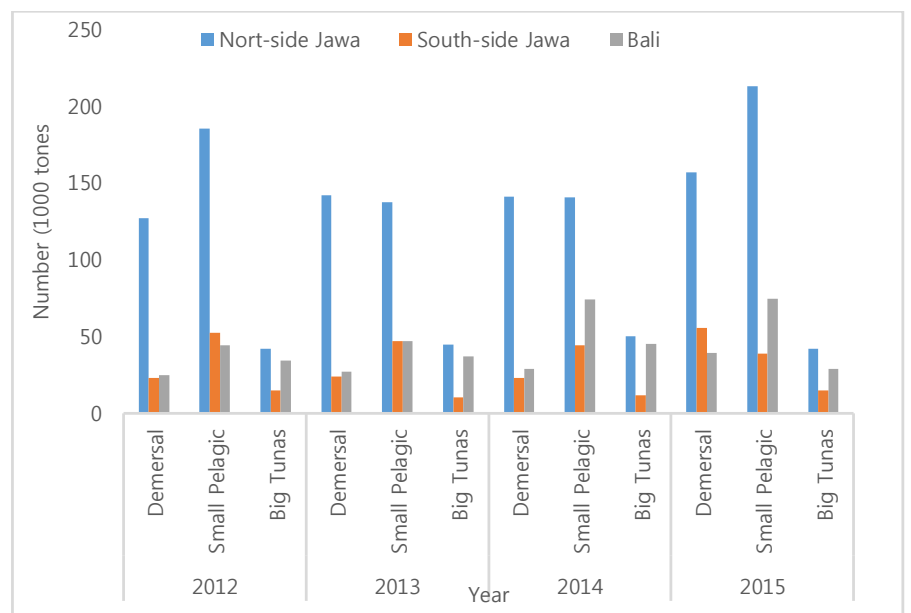

Figure 2. Marine fish Exploited in Java (North and South side of Java) and Bali (including NTB and NTT) 


\section{Marine Fish as Food Resources}

Animal protein requirements, one of which can be met from fish protein or in general contributes to the fulfillment of food supplies for humans (Kent, 1997). Fish resources are an important source of food in the fulfillment of micronutrients that cannot be synthesized by the human body. There is a tendency to decrease the number of capture fisheries and even some areas show a very sharp and even collapsed. (Kent, 1997), demanding attention in increasing the number of fish available to the community. It is estimated that more than $10 \%$ of the world's population suffers from micronutrient deficiency and fatty acid due to decreased availability of fish. The availability of fish resources is very important given the rising human population. Estimated, the human population in 2050 is 9 billion which means it will increase the amount of food consumption around 70-100\% (Godfray et al., 2010). Consumption of nutritional value is an important point in the study of nutritional risks. Currently, about $17 \%$ of the world's population suffers from Zinc deficiency, and nearly one-fifth of pregnant women in the world are iron-deficient anemic and one-third deficient in Vitamin A (Golden et al., 2016).

In recent decades, fishery consumption has become more heterogeneous and dynamic with average daily consumption of fish only about 34 calories per capita. In countries where consumption of fish is high, its consumption value can reach 130 calories per capita (Iceland, Japan, Norway, South Korea). This suggests that fish resources contribute significantly to the intake of animal protein, wherein 150 grams of fish there is about 50-60\% of the daily protein requirement for adults. The fish protein may represent an important component in food in some countries with a low total protein intake level. Food patterns in these countries reveal that fish consumption is very important in helping to increase the ratio of protein and calories. In addition, fish are often a more affordable source of animal protein, not only cheaper than other animal protein sources but more popular. For example, in 2013 in Bangladesh, Cambodia, Ghana, Indonesia, Sierra Leone and Sri Lanka, fish account for about $17 \%$ of animal protein, and $6.7 \%$ of the total protein consumed by the global population. In addition, fish consumed more than 3.1 billion people with an average intake of animal protein per capita of about 20\% (FAO, 2016).

Currently, Indonesian fish consumption on average is about $38.14 \mathrm{~kg}$ of fish/capita/ year. In 2011 , fish consumption value was only about 30.48 fish/capita/ year. With increasing knowledge and level of education, the diversification of protein sources is increasing from the origin of only land animal products (livestock products) to fishery products. In some places, fish consumption is very high compared to livestock products due to geographical and customary factors so that only fishery products are the main source of protein. However, on the island of Java and Bali, the main source of protein is still from farm products such as chicken eggs, chicken meat, beef, cattle meat and small amounts of pork. In general, the increase of fish consumption value from 2011-2015 which experienced a surge of $7.66 \mathrm{fish} / \mathrm{capita} /$ year or increased by 25.13\% (BPS-statistic, 2016). The value of fish consumption in Java is very diverse. The lowest value is in the province of DIY (20.69 kg/capita/year) and the highest in the region of Banten (42.44 kg/capita/year). While in the Province of Bali (33.01 kg/capita/year) is almost the same as West Java $(32.45 \mathrm{~kg} / \mathrm{capita} /$ year) and East Java $(35.06 \mathrm{~kg} /$ capita/year) (Figure 3)

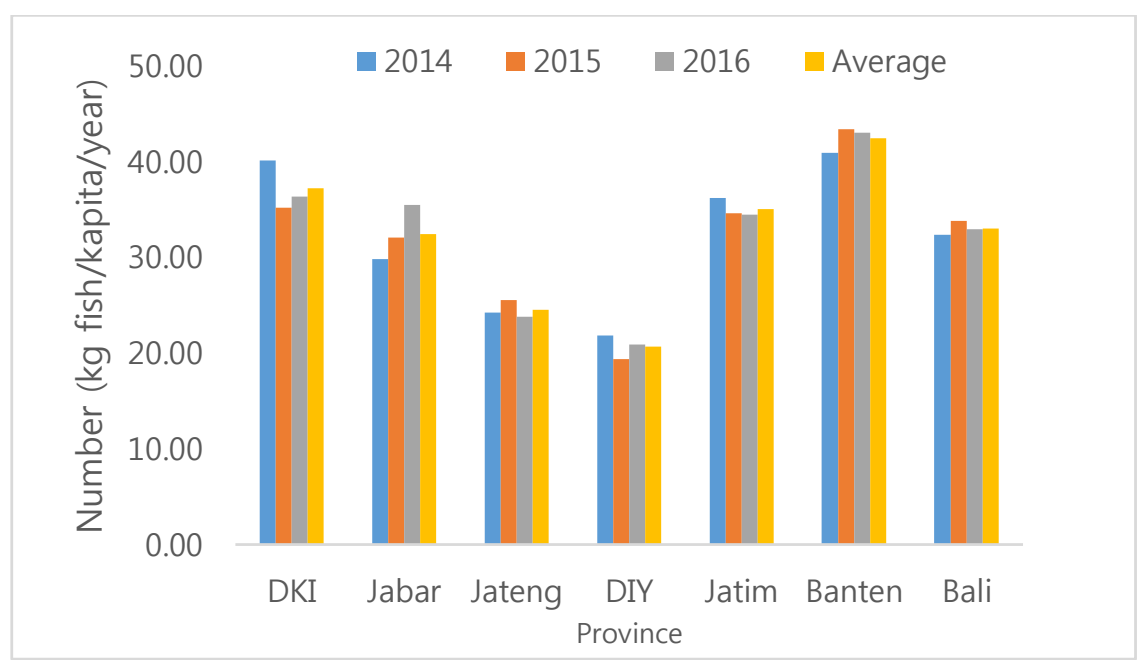

Figure 3. Fish Consumption in Java Island and Bali Island 2014-2016 
Indonesian public awareness of the importance of healthy food is increasingly visible along with the increase in fish consumption (white meat) compared to red meat consumption. This condition is evidenced by the increasing growth of fish consumption from 2013-2014 (BPS, 2017). The level of fish consumption in Indonesia is still relatively low compared to neighboring countries such as Malaysia and Singapore. The low consumption of fish in the country due to a number of aspects that one of them is the lack of information about the importance of fish consumption. Several government programs have been undertaken to increase the value of fish consumption. Minapolitan program is also expected to increase the value of fish consumption as well as the regional superior in increasing regional revenue from its potential (Arnawa et al., 2017).

\section{Management of Fisheries Resources}

Management and practice of fisheries in Indonesia have been focused on the number of catches, not considering the balance of the ecosystem. With such a pattern of management, the impacts are now felt, among others, damage to coral reefs and marine ecosystems, and the occurrence of overfishing in some areas. Increasing capture capacity to increase production targets is not an effective and efficient business, this is because the limitations of fishery stocks that currently exist have decreased. One study conducted in the waters of Pangandaran proves that the rate of decline in fishery production (Nurhayati, 2013).

Fisheries management in Indonesia is considered not optimal, both in capture fisheries and aquaculture, and even this condition has experienced dilemma (Mous et al., 2005). In the fisheries catch sector, there are still many illegal, unreported, and unregulated (IUU) fishing activities (Varkey et al., 2010). This is further exacerbated by over-fishing symptoms in some waters (especially in western Indonesia) (Mous et al., 2005) even though in other regions (Eastern Indonesia) still have considerable potential for exploitation (Widodo, 2003). Over-fishing that occurs in Indonesia is estimated due to the use of fishing gear that is environmentally damaging and certain chemicals that damage the ecological chain and destroy the habitat of fishery resources in the region. This condition is estimated due to the ineffectiveness of the fishery resources management system such as the still weak supervision system of fish resource utilization and the low capacity of human resources owned. In tuna capture fisheries at Pelabuhan Ratu, from studies conducted, almost over $98 \%$ were juvenile yellowfin tuna ( $<85 \mathrm{~cm}$ fork length) captured in March-May 2005 (Mertha et al., 2006). This indicates the absence of regulation of tuna catch size at this time.

Indonesia's capture fishery production volume in 2015 grew by $0.5 \%$ or 36 thousand tons compared to 2014 . With the growth of marine capture fishery production by $0.45 \%$ or 27 thousand tons, the average growth rate of capture fishery production volume in 2010- 2015 growth of 3.24\% (BPS, 2017). The increase of capture fishery production value, the strategy of management of Indonesian marine area is by developing protection through several approaches. One of them is the establishment of protected areas or conservation areas in various forms such as National Parks, Wildlife Sanctuaries, and nature parks.

Conservation areas in Indonesia are conducted in various forms. In terms of area and management, the National Park (NP) becomes the most widespread conservation area compared to other conservation areas and already has a better management unit. Other conservation areas Marine Ecotourism Park (MEP), Marine Nature Recreation Park (MNRP), Marine Sanctuary (MS), Marine Natural Preservation (MNP), and District Marine Conservation Area (DMCA) are distributed throughout Indonesia.

In Java Island, the total area of NP is 217,606 Ha in Pulau Seribu National Park 107,489 Ha (Sambali et al., 2014) in DKI Jakarta and Karimun Jawa National Park (Yusuf, 2007) in Central Java with an area of 110.17 Ha. In Banten, there is MEP with an area of $720 \mathrm{Ha}, 2 \mathrm{MS} 90 \mathrm{Ha}$ in DKI Jakarta and $90 \mathrm{Ha}$ in West Java, and 2 MNPs in West Java with a total area of 1,620 Ha (BPS, 2017).

Growing awareness of the importance of conservation areas, a number of districts throughout the province are making various means to protect the region on its territory embodied in the form of a DMCA. In West Java, there are 3 DMCAs with a total area of 32,476 Ha, whereas in Central Java there are 5 DMCAs with the total region area of $57,722 \mathrm{Ha}$. In DIY, there are 2 DMCAs areas with an area of 3,570 Ha, while Banten only has 1 DMCA area of about 7,391 Ha. In East Java Province has 4 DMCA areas with a total area of 121,606 which is the largest area when compared to DMCA in other provinces in Java. The island of Bali has 1 National Park West Bali National Park (Thoha, 2010) area but does not specifically conduct marine conservation areas although also has a marine area such as Menjangan island. Nevertheless, Bali Province has 3 DMCAs areas spread over several districts on the island of Bali with a total area of $37631 \mathrm{Ha}$. Another conservation area is fishery sanctuary in Java Island spread in Central Java Province $12 \mathrm{Ha}$ and 2 areas in East Java with the total area of $370 \mathrm{Ha}$ (BPS, 2017). The conservation area information indicates that the Marine Protected Area (MPA) is one of the alternatives to protect natural resources such as fish, coral reefs and other useful resources for the future (Gaines et al., 2010; McClanahan et al., 2006). 


\section{Scientific Information and Documentation of Biodiversity}

Some countries have done DNA barcoding on fish resources owned. This makes the molecular information more simple and accessible for various interests and studies such as genetic biology, phylogenic studies, and other biological studies. DNA barcoding designed to provide rapid, accurate, and automatable species identification by standardized gene region as internal species tags (Hebert \& Gregory, 2005) such as COI, Cyt b, 12S rRNA and 16S rRNA. One of the countries closest to Indonesia, Australia has documented 207 species of fish (Ward et al., 2005). India has done DNA barcoding on 115 species of fish from the Carangids family, Clupeids, Scombrids, groupers, Sciaenids, Silverbellies, Mullied, Polynemids, and Sillulids (Lakra et al., 2011). While in Turkey, DNA barcoding was performed on freshwater fish and seawater documenting 89 species of fish from 70 genera, 40 families and 19 orders (Keskİn \& Atar, 2013).

Unfortunately, especially the diversity of marine fish species in Indonesia, have not been fully documented well in the molecular level. Studies in freshwater fish get enough attention either to their preparation of DNA barcode on the fish (Hubert et al., 2008; Hubert et al., 2012; Hubert et al., 2015). Several studies DNA barcoding on certain marine species already done such as shark species (Prehadi et al., 2014), grouper (Antoro et al., 2006), false clown anemonefish (Madduppa et al., 2014), bigeye tuna (Appleyard et al., 2002), yellowfin tuna (Appleyard et al., 2001) and tuna and mackerel (Crandall \& Riginos, 2014; Jackson et al., 2014), short body mackerel (Indaryanto et al., 2015).

\section{Discussion}

Potential of Indonesia catch fishery that is still believed as the potential sector, now need to get a very serious study. This study is not only due to overfishing, but in some areas also reported illegal, unreported and unregulated fishing activities (Varkey et al., 2010). If this continues, the fishery resources of Indonesia will decrease and affect the economic and social sectors. In general, Indonesian catch fisheries catch on small pelagic fish species. This group of fishes plays an important role in the economic life of people in Indonesia, where nearly $75 \%$ of catches (around 4.8 million tons/year) are small pelagic fish (Hendiarti et al., 2005).

Small pelagic fish are grouped into three categories based on population type, ie oceanic population, neritic population and coastal population. In the first group, these small pelagic fish were caught around the Banda Sea and the Java Sea during the monsoon southeast season of August to November. Fish species of this group include Decapterus russelli, Amblygaster sirm, Rastrelliger kanagurta. In the second habitat group of the neritic zone, which can be captured throughout the year by means of seines. In the coastal habitat group, small pelagic fish groups can be found in low quantities throughout the year such as species Sardinella crumenophthalmus and Sardinella gibbosa (Potier \& Sadhotomo, 1995).

Fishery in the Sea of Java, the influence of oceanography in this area is very determining the productivity of the existing fishing catch. Fishermen in this region usually catch fish in the number of areas with purse seine fishing gear. The highest capture in this region is reached in the months of September to November. It is estimated that about 30 species of fish are caught in this small pelagic fish group. The largest group of fish are from the Carangidae family (Decapterus russelli and D. macrosoma), Clupeidea (Sardinella gibbosa and Amblygaster sirm), Scombrids (mackerel Rastrelliger kanagurta) (Nurhakim et al., 1995). Other small pelagic species in the inshore area include Selaroide leptolepis, Sardinella brnachysoma, Rastrelliger brancysoma and Stolephorus sp (Hendiarti et al., 2005).

Unlike the northern side of Java, the southern side of Java is directly opposite the Indian Ocean, which experienced upwelling region in several places. This region is a feeding ground that has a high phytoplankton abundance. From the study in Cilacap area in the type of large pelagic fish such as skipjack (Katsuwonus pelamis), tuna (Thunnus albacares), Istiophorus sp., Scomberomorus sp. Isurus glaucus, and Euthynnus sp. During the southeast monsoon season occurring in the southern region of Java, the composition of chlorophyll-a detected very high and evidenced by high skipjack capture rates. While on the southern side towards the Bali Strait, in upwelling areas this is a small pelagic group of Sardinella species (Hendiarti et al., 2005). It is estimated that with many areas of small pelagic fish, then it is also found that Tuna is a predator. The tuna population was not found directly with high primary productivity, but Tuna aggregation is often found to be close to frontier regions that are areas of plankton and micro-nekton growth (Lehodey et al., 1998).

In the area of the strait of Bali, Sardinella lemuru is the most dominant species and almost $90 \%$ of the total value of catches in this region. The highest catch of this species occurred in September to November, but there was an 
increase in the number of catches in March to April although not as much as in September-November (Hendiarti et al., 2005).

By looking at the high potential of fisheries in Indonesia, the management of fishery resources, especially marine fishery requires adequate and accurate information tools. The information is currently very limited due to limitations in the provision of data and information. Researchers that provide information on marine fish resources are still very few and even still dominated by foreign researchers doing research collaboration with a number of institutions in Indonesia such as LIPI, universities and international NGOs such as WWF and TNC. With the development of technology, documentation of fishery resources also progressed without leaving conventional methods. The overall identification of the fishery resources is a fundamental requirement. Rapid and accurate identification can now be done by performing DNA barcoding of the species owned. Although there is still a debate, this barcoding DNA technology becomes a pretty powerful method (Hebert \& Gregory, 2005).

In the analysis of marine resource management, some references state that management paradigm with reference to MSY value should start at leave due to several disadvantages which then spawns misinterpreted output (Mous et al., 2005). Another possible method is the ecosystem-based management that prioritizes ecological and cycle roles in the environment. The goal of ecosystem-based management is to maintain ecosystem health and sustainability (Link, 2002). The calculation of MSY value in Indonesia still allows the value of error big enough considering the data into the initial information collected by sampling method is expected to represent the fishery resources are measured. In addition to considering the method of estimation of fishery resources owned, the action of protection of natural resources must also be done one of them by increasing the role of the conservation area. The current use of conservation areas is not only for education and research, but sustainable use can actually bring in better revenue. One of the utilization of national park area is ecotourism. Ecotourism is developed as one of the responsible tourism that keeps the natural resources sustainability and utilizes according to the ability of the environment. In the application, ecotourism should also be done in an effort to empower local community so that the synergy between utilization and the generated economy can be side by side (Scheyvens, 1999).

\section{Conclusion}

Increased attention of the Indonesian government to marine resources need to be coupled with the efforts of conservation area as well as documentation of marine resources owned. The potential of marine resources is still in the stage of the preparation of information both morphological and molecular approaches. This documentation is very important and useful in various fields of biology studies and oceanography on marine resources. The importance of marine biodiversity in Indonesia at the global level is expected to be supported by integrated and simultaneous research and study of marine resources to provide useful information in the determination of better marine resource management policies in the future.

\section{Acknowledgments}

The author would like to thank the editor for their valuable time and advice. This work is part of the preparation of DNA barcoding of commercial fishes in Java and Bali. This project was supported by a grant Indonesian Endowment Fund for Education (LPDP) scholarship under Beasiswa Unggulan Dosen Indonesia-Luar Negeri (BUDI-LN) Batch I 2016 (Number:PRJ-3635 /LPDP.3/2016). 


\section{References}

Antoro, S., Na-Nakorn, U. and Koedprang, W. 2006. Study Of Genetic Diversity Of Orange-Spotted Grouper, Epinephelus Coioides, From Thailand And Indonesia Using Microsatellite Markers. Marine Biotechnology, 8, 17-26.

Appleyard, S., Grewe, P., Innes, B. and Ward, R. 2001. Population Structure Of Yellowfin Tuna (Thunnusalbacares) In The Western Pacific Ocean, Inferred From Microsatellite Loci. Marine Biology, 139, 383-393.

Appleyard, S., Ward, R. and Grewe, P. 2002. Genetic Stock Structure Of Bigeye Tuna In The Indian Ocean Using Mitochondrial Dna And Microsatellites. Journal Of Fish Biology, 60, 767-770.

Arnawa, I. K., Sukerta, I. M., Martiningsih, N. G. A. E. and Astuti, P. S. 2017. Minapolitan Area Development Strategy: An Effort To Increase Fisherman Income, Gianyar Regency, Bali Indonesia. International Journal Of Life Sciences (Ijls), 1, 39-47.

Bps 2017. Statistic Of Marine And Coastal Resources 2016. Book, 259.

Carpenter, K. E. and Springer, V. G. 2005. The Center Of The Center Of Marine Shore Fish Biodiversity: The Philippine Islands. Environmental Biology Of Fishes, 72, 467-480.

Crandall, E. D. and Riginos, C. 2014. Magnificent Dimensions, Varied Forms, And Brilliant Colors: The Molecular Ecology And Evolution Of The Indian And Pacific Oceans. Bulletin Of Marine Science, 90, 1-11.

Eschmeyer, W. N., Fricke, R., Fong, J. D. and Polack, D. A. 2010. Marine Fish Diversity: History Of Knowledge And Discovery (Pisces). Zootaxa, 2525, 19-50.

Fao 2016. Aquaculture Department (2010) The State Of World Fisheries And Aquaculture. Food And Agriculture Organization Of The United Nations, Rome.

Gaines, S. D., White, C., Carr, M. H. and Palumbi, S. R. 2010. Designing Marine Reserve Networks For Both Conservation And Fisheries Management. Proceedings Of The National Academy Of Sciences, 107, 1828618293.

Godfray, H. C. J., Beddington, J. R., Crute, I. R., Haddad, L., Lawrence, D., Muir, J. F., Pretty, J., Robinson, S., Thomas, S. M. and Toulmin, C. 2010. Food Security: The Challenge Of Feeding 9 Billion People. Science, 327, 812-818.

Golden, C., Allison, E. H., Cheung, W. W., Dey, M. M., Halpern, B. S., Mccauley, D. J., Smith, M., Vaitla, B., Zeller, D. and Myers, S. S. 2016. Fall In Fish Catch Threatens Human Health. Nature, 534, 317-320.

Gulland, J. A. 1983. Fish Stock Assessment: A Basic Of Basic Methods, Fonds Des Nations Unis Pour L'alimentation Et L'agriculture (Fao).

Hebert, P. D. and Gregory, T. R. 2005. The Promise Of Dna Barcoding For Taxonomy. Systematic Biology, 54, 852859.

Hendiarti, N., Aldrian, E., Amri, K., Andiastuti, R., Sachoemar, S. I. and Wahyono, I. B. 2005. Pelagic Fish Catch. Oceanography, 18, 113.

Hubalkova, Z., Kralik, P., Tremlova, B. and Rencova, E. 2007. Methods Of Gadoid Fish Species Identification In Food And Their Economic Impact In The Czech Republic: A Review. Veterinarni Medicina-Praha-, $52,273$.

Hubert, N., Hadiaty, R. K., Paradis, E. and Pouyaud, L. 2012. Cryptic Diversity In Indo-Australian Rainbowfishes Revealed By Dna Barcoding: Implications For Conservation In A Biodiversity Hotspot Candidate. Plos One, 7 , E40627.

Hubert, N., Hanner, R., Holm, E., Mandrak, N. E., Taylor, E., Burridge, M., Watkinson, D., Dumont, P., Curry, A. and Bentzen, P. 2008. Identifying Canadian Freshwater Fishes Through Dna Barcodes. Plos One, 3, E2490.

Hubert, N., Wibowo, A., Busson, F., Caruso, D., Sulandari, S., Nafiqoh, N., Pouyaud, L., Rüber, L., Avarre, J.-C. and Herder, F. 2015. Dna Barcoding Indonesian Freshwater Fishes: Challenges And Prospects. Dna Barcodes, 3, 144-169.

Hutama, A. A., Hadiaty, R. K. and Hubert, N. 2017. Biogeography Of Indonesian Freshwater Fishes: Current Progress. Treubia, 43, 17-30.

Indaryanto, F. R., Imai, H. and Wardiatno, Y. 2015. Genetic Variation Of Short Body Mackerel, Rastrelliger Brachysoma Of Jawa Island, Indonesia Based On Mtdna Control Region Sequences. Aquaculture, Aquarium, Conservation \& Legislation-International Journal Of The Bioflux Society (Aacl Bioflux), 8.

Jackson, A. M., Erdmann, M. V., Toha, A. H. A., Stevens, L. A. and Barber, P. H. 2014. Phylogeography Of Commercial Tuna And Mackerel In The Indonesian Archipelago. Bulletin Of Marine Science, 90, 471-492.

Kent, G. 1997. Fisheries, Food Security, And The Poor. Food Policy, 22, 393-404.

Keskin, E. and Atar, H. H. 2013. Dna Barcoding Commercially Important Fish Species Of Turkey. Molecular Ecology Resources, 13, 788-797.

Kvasnička, F. 2005. Capillary Electrophoresis In Food Authenticity. Journal Of Separation Science, 28, 813-825. 
Lakra, W., Verma, M., Goswami, M., Lal, K. K., Mohindra, V., Punia, P., Gopalakrishnan, A., Singh, K., Ward, R. D. and Hebert, P. 2011. Dna Barcoding Indian Marine Fishes. Molecular Ecology Resources, 11, 60-71.

Lehodey, P., Andre, J. M., Bertignac, M., Hampton, J., Stoens, A., Menkès, C., Mémery, L. and Grima, N. 1998. Predicting Skipjack Tuna Forage Distributions In The Equatorial Pacific Using A Coupled Dynamical Bio-Geochemical Model. Fisheries Oceanography, 7, 317-325.

Link, J. S. 2002. What Does Ecosystem-Based Fisheries Management Mean. Fisheries, 27, 18-21.

Madduppa, H. H., Timm, J. and Kochzius, M. 2014. Interspecific, Spatial And Temporal Variability Of SelfRecruitment In Anemonefishes. Plos One, 9, E90648.

Mcclanahan, T. R., Marnane, M. J., Cinner, J. E. and Kiene, W. E. 2006. A Comparison Of Marine Protected Areas And Alternative Approaches To Coral-Reef Management. Current Biology, 16, 1408-1413.

Mcmanus, J. W. Zonation Among Demersal Fishes Of Southeast Asia: The Southwest Shelf Of Indonesia. Coastal Zone'89: Proceedings Of The Sixth Symposium On Coastal And Ocean Management, 1989. Publ By Asce.

Mertha, I. G. S., Nurhuda, M. and Nasrullah, A. 2006. Perkembangan Perikanan Tuna Di Pelabuhanratu. Jurnal Penelitian Perikanan Indonesia. Issn, 0853-5884.

Mous, P. J., Pet, J., Arifin, Z., Djohani, R., Erdmann, M., Halim, A., Knight, M., Pet-Soede, L. and Wiadnya, G. 2005. Policy Needs To Improve Marine Capture Fisheries Management And To Define A Role For Marine Protected Areas In Indonesia. Fisheries Management And Ecology, 12, 259-268.

Nurhakim, S., Durand, J.-R., Potier, M. and Sadhotomo, B. 1995. The State Of Exploitation Of Small Pelagie Fishes By Large And Medium Purse Seiners In The Java Sea. Proeeedings Of Soeio-Eeonomies, Innovation And Management Of The Java Sea Pelagie Fisheries, 37.

Nurhayati, A. 2013. Analisis Potensi Lestari Perikanan Tangkap Di Kawasan Pangandaran. Jurnal Akuatika, 4.

Nuryadin, D., Syaifudin, N., Handika, R., Setyobudi, R. H. and Udjianto, D. W. 2016. The Economic Of Marine Sector In Indonesia. Aquatic Procedia, 7, 181-186.

Patterson, K. 1992. Fisheries For Small Pelagic Species: An Empirical Approach To Management Targets. Reviews In Fish Biology And Fisheries, 2, 321-338.

Potier, M. and Sadhotomo, B. 1995. Exploitation Of The Large And Medium Seiners Fisheries.

Prehadi, P., Sembiring, A., Kurniasih, E. M., Rahmad, R., Arafat, D., Subhan, B. \& Madduppa, H. H. 2014. DNA Barcoding And Phylogenetic Reconstruction Of Shark Species Landed In Muncar Fisheries Landing Site In Comparison With Southern Java Fishing Port. Biodiversitas Journal Of Biological Diversity, 16.

Rehbein, H., Mackie, I. M., Pryde, S., Gonzales-Sotelo, C., Medina, I., Perez-Martin, R., Quinteiro, J. and ReyMendez, M. 1999. Fish Species Identification In Canned Tuna By Pcr-Sscp: Validation By A Collaborative Study And Investigation Of Intra-Species Variability Of The Dna-Patterns. Food Chemistry, 64, 263-268.

Roberts, C. M., Mcclean, C. J., Veron, J. E., Hawkins, J. P., Allen, G. R., Mcallister, D. E., Mittermeier, C. G., Schueler, F. W., Spalding, M. and Wells, F. 2002. Marine Biodiversity Hotspots And Conservation Priorities For Tropical Reefs. Science, 295, 1280-1284.

Sambali, H., Yulianda, F., Bengen, D. G. \& Kamal, M. M. 2014. Analisis Kelembagaan Pengelola Taman Nasional Laut Kepulauan Seribu. Jurnal Sosial Ekonomi Kelautan Dan Perikanan, 9, 105-113.

Scheyvens, R. 1999. Ecotourism And The Empowerment Of Local Communities. Tourism Management, 20, 245249.

Sharp, G. D. 1996. Oceanography Of The Indonesian Archipelago And Adjacent Areas. Baseline Studies Of Biodiversity: The Fish Resources Of Western Indonesia Iclarm Stud Rev, 321.

Strauss, R. E. \& Bond, C. E. 1990. Taxonomic Methods: Morphology. Methods For Fish Biology. American Fisheries Society, Bethesda, Maryland, 109-140.

Teletchea, F. 2009. Molecular Identification Methods Of Fish Species: Reassessment And Possible Applications. Reviews In Fish Biology And Fisheries, 19, 265.

Teletchea, F., Maudet, C. \& Hänni, C. 2005. Food And Forensic Molecular Identification: Update And Challenges. Trends In Biotechnology, 23, 359-366.

Thoha, H. 2010. Kelimpahan Plankton Di Ekosistem Perairan Teluk Gilimanuk, Taman Nasional, Bali Barat. Makara Journal Of Science.

Varkey, D. A., Ainsworth, C. H., Pitcher, T. J., Goram, Y. \& Sumaila, R. 2010. Illegal, Unreported And Unregulated Fisheries Catch In Raja Ampat Regency, Eastern Indonesia. Marine Policy, 34, 228-236.

Wafar, M., Venkataraman, K., Ingole, B., Khan, S. A. \& Lokabharathi, P. 2011. State Of Knowledge Of Coastal And Marine Biodiversity Of Indian Ocean Countries. Plos One, 6, E14613.

Ward, R. D., Zemlak, T. S., Innes, B. H., Last, P. R. \& Hebert, P. D. 2005. Dna Barcoding Australia's Fish Species. Philosophical Transactions Of The Royal Society Of London B: Biological Sciences, 360, 1847-1857. 
Widodo, J. Pengkajian Stok Sumber Daya Ikan Laut Indonesia Tahun 2002. Prosiding Forum Pengkajian Stok Ikan Laut Di Perairan Indonesia. Jakarta, 2003. 23-24.

Wiryawan, B., Marsden, B., Susanto, H., Mahi, A., Ahmad, M. \& Poespitasasri, H. 1999. Lampung Coastal Resources Atlas. Government Of Lampung Province And Coastal Resources Management Project (Coastal Resources Centre, University Of Rhode Island And Centre For Coastal And Marine Resources Studies, Bogor Agricultural University). Bandar Lampung, Indonesia.

Yusuf, M. 2007. Kebijakan Pengelolaan Sumberdaya Pesisir Dan Laut Kawasan Taman Nasional Karimunjawa Secara Berkelanjutan.

Widodo, J. 2003. Pengkajian Stok Sumber Daya Ikan Laut Indonesia Tahun 2002. In Prosiding Forum Pengkajian Stok Ikan Laut Di Perairan Indonesia. Jakarta (Pp. 23-24).

Wiryawan, B., Marsden, B., Susanto, H. A., Mahi, A. K., Ahmad, M., and Poespitasasri, H. (1999). Lampung Coastal Resources Atlas. Government of Lampung Province and Coastal Resources Management Project (Coastal Resources Centre, University of Rhode Island And Centre For Coastal And Marine Resources Studies, Bogor Agricultural University). Bandar Lampung, Indonesia.

Yusuf, M. 2007. Kebijakan Pengelolaan Sumberdaya Pesisir Dan Laut Kawasan Taman Nasional Karimunjawa Secara Berkelanjutan. 